\title{
PROTECTING NATIONAL PARKS FROM DEVELOPMENTS BEYOND THEIR BORDERS
}

The accumulated impact of such factors as population growth, ${ }^{1}$ acid rain, ${ }^{2}$ and energy and resource development ${ }^{3}$ are threatening the sanctity of our nation's parks. As noted in a recent congressional report, activities beyond our parks' boundaries are increasingly undermining the quality of the parks themselves:

Most of these great parks were at one time pristine areas surrounded and protected by vast wilderness regions. Today, with their surrounding buffer zones gradually disappearing, many of these parks are experiencing significant and widespread adverse effects associated with external encroachment. . . . The most frequently identified external threats included: Industrial and commercial development projects on adjacent lands; air pollutant emissions, often associated with facilities located considerable distances from the affected parks; urban encroachment; and roads and railroads. ${ }^{4}$

National _concern for the preservation of unique areas of the American landscape was first clearly manifested in 1872 when Congress set aside over two million acres in the territories of Wyoming,

1 Between 1970 and 1980, there were dramatic population increases in the mountain and Pacific northwest states where many of the major national parks are located. In the mountain states, for example, population increases in the metropolitan areas ranged from $15.4 \%$ (Wyoming) to $86 \%$ (Nevada), and increases in the nonmetropolitan areas ranged from $13.8 \%$ (Montana) to $52.3 \%$ (Nevada). In all but two of the mountain states, the nonmetropolitan population grew by $25 \%$ or more. See BUREAU OF THE Census, U.S. Dep't of Commerce, Metropolitan and Non-metropolitan Area Population-States, 1960-1980, Statistical Abstract of the United STATES (103d ed. 1982-83). Although population growth in nonmetropolitan areas may be a more direct problem, urban population growth can also have a deleterious impact by, for example, aggravating the problems of air and water pollution.

${ }^{2}$ For surveys of the causes, consequences, and legal issues surrounding acid rain, see generally Note, Acid Rain: Causes, Effects, and Remedies, 3 Stan. EnvTL. L. Soc'y ANN. 118 (1980-81); Note, Umbrella Equities: Use of Federal Common Law Nuisance to Catch the Fall of Acid Rain, 21 URB. L. ANN. 143 (1981); Note, Controlling Acid Rain: The Clear Air Act and Federal Common Law Nuisance, 84 W. VA. L. REV. 1135 (1982).

3 See, e.g., Sierra Club v. Andrus, 487 F. Supp. 443 (D.D.C. 1980) (challenging the Secretary of the Interior's failure to assert federal water rights in order to prevent the construction in northern Arizona and southern Utah of energy projects that would disrupt waters flowing through Grand Canyon National Park).

H.R. REP. No. 170, 98th Cong., 1st Sess. 2-3 (1983). 
Montana, and Idaho to create Yellowstone National Park. ${ }^{5}$ That action was particularly remarkable in that the primary object of federal land policy up until then had been to dispose of the government's vast holdings of public lands. ${ }^{6}$ In 1916 , the federal commitment to preservation was codified when Congress enacted legislation establishing a National Park Service to oversee the growing network of national parks. ${ }^{7}$ The wording of that statute, still in effect today, obligates the Park Service "to conserve the scenery and the natural and historic objects and the wild life therein and to provide for the enjoyment of the same in such manner and by such means as will leave them unimpaired for the enjoyment of future generations." of national parks has expanded to include well over three hundred areas encompassing over one hundred million acres of land. Much of the most beautiful and historically significant land in the United States is thus entrusted to the care of the National Park Service. ${ }^{9}$

Congress has traditionally sought to endow each new park with lands sufficient to surround and protect the focal points of the park. Whenever the focal points have been threatened by outside activity, the simplest and most effective response has been for the government to acquire additional surrounding land as insulation. ${ }^{\mathbf{1 0}}$ It is becoming

- See Act of Mar. 1, 1872, ch. 24, 17 Stat. 32 (codified as amended at 16 U.S.C. $\S \S 21-40$ (1982)). The Act described the land set aside as "a public park or pleasuringground for the benefit and enjoyment of the people" and dictated that the Secretary of the Interior promulgate rules and regulations to "provide for the preservation, from injury or spoliation, of all timber, mineral deposits, natural curiosities, or wonders within said park, and their retention in their natural condition." 17 Stat. at 32-33. For an early history of Yellowstone Park, see J. Ise, Our National Park Policy: A Critical History 13-50 (1961).

- See generally P. Gates, History of Public Land Law Development 1-32 (1968).

7 National Park Service Organic Act, 39 Stat. 535-36 (1916) (codified as amended at 16 U.S.C. $\$ \S 1-20 \mathrm{~g}(1982))$.

- 16 U.S.C. \& 1 (1982).

- For a brief statistical summary of the National Park System, see W. Everhart, The National PARK Service app. B (1983). Everhart provides information by category on the number and acreage of national parks, national monuments, national lakeshores, and other protected sites.

10 The government's most recent attempt to protect a park through land acquisition occurred in response to the disruption of Redwood National Park by neighboring timber operations. Litigation eventually led to congressional action. The pertinent section of the governing statute, as amended in 1978, authorizes the Secretary to acquire land from those who own land on the periphery of the park and on watersheds tributary to streams within the park "to afford as full protection as is reasonably possible to the timber, soil, and streams." See 16 U.S.C. $\$ 79 \mathrm{c}(\mathrm{e})(1982)$.

Many of the statutes establishing new national parks and recreation areas include sections describing specific plots of land to be acquired in the future. See, for example, detailed provisions as to acquisition procedures for several new national recreation areas: Golden Gate National Recreation Area, id. § 460bb-2; Gateway National Recreation Area, id. $\S 460 \mathrm{cc}-1$. 
clearer, however, that this simple response is inadequate for long-term park protection. Undeveloped land adjacent to parks is becoming increasingly scarce and prohibitively expensive. ${ }^{11}$ Moreover, the concept of buffer protection, at least theoretically, knows no bounds. As more than one critic has asked: "Where does the buffer end? Does it stretch from the Atlantic to the Pacific?"12

The first two parts of this Comment will focus on several alternatives to buffer zone protection for the national parks. Part I briefly examines the limited effectiveness of the traditional approaches of nuisance and public trust doctrine in protecting the national parks. Part II analyzes the limited role that direct congressional action has played in addressing threats to specific parks. Part II then discusses and critiques H.R. $2379,{ }^{13}$ a bill currently pending in Congress and designed to increase the Secretary of the Interior's responsibilities to the parks. Finally, Part III suggests several amendments that will ensure that the bill, when enacted, is adequate to the important task of protecting the national parks from harmful developments beyond their borders.

\section{The Traditional Approaches}

An analysis of the value of nuisance and public trust doctrine as devices for protecting our national park system from developments beyond park boundaries is worth undertaking on several grounds. Both doctrines have been used effectively in the recent past to address developments harmful to federal lands and interests. Although legislation and judicial interpretation have limited their scope, these doctrines continue to be the subject of scholarly debate. Furthermore, the two doctrines provide mechanisms by which the judiciary might assume a role in the protection of national parks. To the extent the role of the legislative process in addressing this problem is limited, such a mechanism for judicial intervention is desirable.

\section{A. Nuisance Law}

The Second Restatement of Torts defines a private nuisance as "a

11 For a general understanding of the difficulties involved in buffer protection, see Sax, Buying Scenery: Land Acquisitions for the National Park Service, 1980 DukE L.J. 709; cf. Lambert, Private Landholdings In The National Parks: Exainples From Yosemite National Park and Indiana Dunes National Lakeshore, 6 HARv. ENVTL. L. REv. 35 (1982) (endorsing land acquisition as best method for dealing with private landholdings within national parks).

${ }_{12}$ Battle Over the Wilderness, NewsweEk, July 25, 1983, at 22, 29 (quoting Assistant Secretary of the Interior Ray Arnett).

1s H.R. 2379, 98th Cong., 1st Sess. (1983). See infra note 102. 
nontrespassory invasion of another's interest in the private use and enjoyment of land,"14 and a public nuisance as "an unreasonable interference with a right common to the general public."15 Whether one considers the government to be analogous to a private landowner in possession of the national parks or whether one considers the use of those parks to be a right common to all, nuisance theories would seem to be ideally suited as authority for the government to bring lawsuits to control the detrimental activities of property owners living adjacent to the parks. Indeed, one commentator has stated that "the federal government has always had the power to enjoin activities that create nuisances on federal lands." ${ }^{16}$ Similarly, a federal district court recently asserted: "The government has, with respect to its own lands, the rights of an ordinary proprietor to maintain its possession and to prosecute trespassers. It may deal with such lands precisely as a private individual may deal with his property."17 Despite these sweeping assertions, nuisance cases involving the federal government as plaintiff have been relatively scarce.

Nuisance actions typically involve disputes between neighboring individual property owners and are litigated in state courts, subject to state laws. ${ }^{18}$ In nuisance actions brought by the federal government, however, the claims have traditionally been litigated in federal courts under federal common law. ${ }^{19}$ A typical example is the 1905 case of United States $v$. Luce. ${ }^{20}$ In Luce, the federal government initiated suit against a Delaware Bay fish factory that was producing "offensive

14 Restatement (SeCOND) OF ToRTs § 821D (1979).

15 Id. \& $821 \mathrm{~B}$.

16 Tarlock, For Whom the National Parks? (Book Review), 34 STAN. L. Rev. 255, 271 (1981) (reviewing J. SAX, Mountains Without HaNDrails: RefLeCtions on the National Parks (1980)).

${ }_{17}$ United States v. Osterlund, 505 F. Supp. 165, 167 (D. Colo. 1981) (citing Camfield v. United States, 167 U.S. 518, 524 (1897)) (granting motion by United States for summary judgment against a trespasser who for some years had inadvertently occupied, farmed, and lumbered part of Arapahoe-Roosevelt National Forest), aff d, 671 F.2d 1267 (10th Cir. 1982).

${ }_{18}$ See generally W. Prosser, Handbook of THe LaW of TorTs 571-612 (4th ed. 1971).

${ }^{19}$ Nuisance actions brought by the United States as landowner are virtually nonexistent in state court reporters. As examples of situations in which the United States did take some action in state court, see Cotton v. United States, 52 U.S. (11 How.) 229 (1850) (trespass action against an individual who was cutting trees on public lands initiated by the United States in the Superior Court of West Florida); Commonwealth v. National Gettysburg Battlefield Tower, Inc., 454 Pa. 193, 195 n.1, 311 A.2d 588, 589 n.1 (1973) (in a case brought by Commonwealth of Pennsylvania to halt construction of a viewing tower adjacent to Gettysburg National Park, the Park Service Advisory Council "finally came out with a report recommending that the United States government assist the Commonwealth in opposing the construction of the tower").

20141 F. 385 (C.C.D. Del. 1905). 


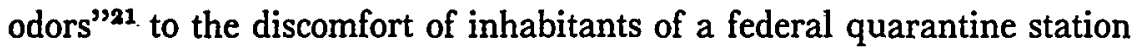
located downwind. In issuing an injunction against the factory, the court stated: "That the government, in the absence of a plain, adequate and complete remedy at law has a right to maintain an injunction bill to restrain a nuisance materially and injuriously affecting the occupancy of its own property there can be no doubt.",22

- Although the Supreme Court's decision in Erie Railroad $v$. Tompkins $^{23}$ cut back on the federal common law, the decision did not abrogate the federal common law of nuisance. In the 1970's, numerous nuisance cases involving interstate pollution were brought, thus generating a substantial body of federal common law. ${ }^{24}$

A 1972 Supreme Court decision, Illinois $v$. City of Milwaukee, ${ }^{25}$ paved the way. The suit was brought by the state of Illinois, which claimed that a number of Wisconsin cities and sewerage commissions were allowing improperly treated sewage to be discharged into Lake Michigan. ${ }^{28}$ Justice Douglas's opinion for a unanimous Court stated that federal courts, under general federal question jurisdiction, ${ }^{27}$ have the power to order the abatement of interstate water pollution affecting

21 Id. at 390.

22 Id. at 419.

28304 U.S. 64 (1938). For general discussions of federal common law, see Friendly, In Praise of Erie-And Of The New Federal Common Law, 39 N.Y.U. L. REv. 383 (1964); Hill, The Law-Making Power of the Federal Courts: Constitutional Preemption, 67 Colum. L. REv. 1024 (1967); Comment, Erie Limited: The Confines of State Law in the Federal Courts, 40 CoRNell L.Q. 561 (1955).

As stated more recently by Justice Rehnquist, "When Congress has not spoken to a particular issue, however, and when there exists a 'significant conflict between some federal policy or interest and the use of state law,' . . . the Court has found it necessary, in a 'few and restricted' instances . . . to develop federal common law." City of Milwaukee v. Illinois, 451 U.S. 304, 313.(1981) (citations omitted).

34 For collections of cases, see W. RoDgers, ENvironmental LAw $\S 2.12$ (1977); Annot., 29 A.L.R. FED. 137 (1976). For some of the early commentary on the emergence of a federal common law cause of action for interstate pollution, see Comment, Federal Common Law and Interstate Pollution, 85 HARv. L. REv. 1439 (1972) (arguing that courts are poorly qualified to make law in the environmental area but well-qualified to apply appropriate remedies under environmental statutes); Note, Federal Jurisdiction-Environmental Law-Nuisance-State Ecological Rights Arising Under Federal Common Law, 1972 Wis. L. REv. 597 (discussing origins of federal common law of nuisance and examining post-Erie federal common law nuisance cases).

23406 U.S. 91 (1972).

${ }^{26}$ Id. at 93. The Court entertained the suit under its power of original jurisdiction over cases to which a state is a party. U.S. CoNST. art. III, $\S 2, \mathrm{cl}$. 2 . However, the Court noted that the exercise of Supreme Court jurisdiction in such cases is not mandatory and decided that this case had to be brought in federal district court. 406 U.S. at 108.

2728 U.S.C. $\$ 1331$ (a) (1970) provided that "[t]he district courts shall have original jurisdiction of all civil actions wherein the matter in controversy exceeds the sum or value of $\$ 10,000$, exclusive of interest and costs, and arises under the Constitution, laws, or treaties of the United States." 
navigable bodies of water: "We see no reason not to give 'laws' its natural meaning . . . and therefore conclude that $\S 1331$ [of title 28] jurisdiction will support claims founded upon federal common law as well as those of a statutory origin." 28 The Court noted, however, that the power to fashion federal common law is limited to situations "where there is an overriding federal interest in the need for a uniform rule of decision or where the controversy touches basic interests of federalism." $"$ 29

The Court went on to caution that "[i]t may happen that new federal laws and new federal regulations may in time preempt the field of common law of nuisance." 30 In this case, however, the Court ruled that the federal common law claim for abatement of the pollution was not preempted by the Federal Water Pollution Control Act ${ }^{31}$ and remanded to the district court for consideration of the merits of the claim. ${ }^{32}$

The Illinois $v$. City of Milwaukee decision spawned a series of related federal common law of nuisance cases during the 1970 's. ${ }^{\text {s3 }}$ Notable among these, especially from the perspective of park protection, was United States $v$. Atlantic-Richfield Co. ${ }^{34}$ In that case, the government sued for a court order to decrease an aluminum reduction plant's emissions of fluoride. The government alleged that the emissions were damaging trees and wildlife in Montana's Flathead National Forest and Glacier National Park. In denying the defendant's motion to dismiss, the federal district court ruled that the federal common law of nuisance

28406 U.S. at 100.

29 Id. at 105 n.6.

so Id. at 107 .

31 Id. at 104. The statutory language that the Court considered appears at 33 U.S.C. §§ $1251-1376$ (1970 \& Supp. II 1972).

32406 U.S. at 108. On remand, the district court denied the defendants' motion to dismiss for failure to state a claim upon which relief could be granted. Illinois v. City of Milwaukee, 366 F. Supp. 298, 302 (N.D. Ill. 1973). The case eventually reached the United States Court of Appeals for the Seventh Circuit, which, after ordering extensive supplementary briefing, substantially modified the district court's decree and remanded the case with instructions to enter an injunctive order against the effluents consistent with the circuit opinion. 599 F.2d 151 (7th Cir. 1979).

ss See, e.g., United States v. Stoeco Homes, Inc., 359 F. Supp. 672 (D.N.J. 1973) (government entitled to injunctive relief from dredging, filling, and construction activities of defendant in a navigable waterway in New Jersey), vacated on other grounds and remanded with instructions to modify the injunction, 498 F.2d 597 (3d Cir. 1974), cert. denied, 420 U.S. 927 (1975); United States ex rel. Scott v. United States Steel Corp., 356 F. Supp. 556 (N.D. Ill. 1973) (granting government's petition to restrain steel producer from discharging wastes into Lake Michigan); United States v. Ira S. Bushey \& Sons, Inc., 346 F. Supp. 145 (D. Vt. 1972) (granting government's request for order that defendant take greater precautions to avoid oil spillages in Lake Champlain).

si 478 F. Supp. 1215 (D. Mont. 1979). 
had not been abolished by federal statute. ${ }^{35}$ Within the last few years, however, courts have ruled that federal legislation has preempted federal common law in litigation involving interstate water $^{36}$ and air $^{37}$ pollution.

Although federal legislation has preempted federal common law in the specific context of pollution, a more general body of federal common law of nuisance may remain intact. For example, the recent case of United States $v$. County Board ${ }^{38}$ involved an unsuccessful attempt by the government to invoke federal nuisance law to halt the construction of high-rise towers in Arlington, Virginia. The government alleged that the completed towers "would be visual intrusions on the monumental core" ${ }^{39}$ of Washington, D.C. Although the injunction was denied, ${ }^{40}$ the court acknowledged that the Attorney General of the United States "has standing to institute and conduct litigation to protect the rights and properties of the United States."11 This case establishes that, at least in situations where statutory remedies are nonexistent, a federal nuisance doctrine may exist. ${ }^{42}$

If nuisance law has been of - at most-limited use as a device for protecting federal lands and interests from outside encroachments, some reasons can be found in the many limitations to the doctrine and obstacles to its implementation. ${ }^{43}$ One major obstacle to effective use is that

ss It is my opinion that Congress did not divest the United States of the right to sue for injunctive relief in air pollution cases affecting its property. There is no express language in the [Federal Clean Air] act which divests the United States of its injunctive remedies. . . .

It seems to me that the language of the act suggests that the federal government does retain its common law rights.

Id. at 1218-19.

36 Middlesex County Sewerage Auth. v. National Sea Clammers Ass'n, 453 U.S. 1,22 (1981) ("TThe federal common law of nuisance in the area of water pollution is entirely pre-empted by the more comprehensive scope of the FWPCA [Federal Water Pollution Control Act], which was completely revised after the decision in Illinois $v$. Milwaukee.").

${ }^{37}$ E.g., United States v. Kin-Buc, Inc., 532 F. Supp. 699 (D.N.J. 1982) (ruling that provisions of the Clear Air Act have preempted federal common law).

s8 487 F. Supp. 137 (E.D. Va. 1979).

so $I d$. at 143 .

10 The court ruled that the government had failed to prove the existence of a public nuisance. Id. at 144 .

4I Id. at 141. The court noted, "Although the Attorney General concedes that the United States has no constitutional or statutory right to regulate land use in Rosslyn-he claims the United States, as a Virginia property owner, has the right to question the validity of a nearby zoning that affects its property." Id.

12 See W. Rodgers, supra note 24; Annot., supra note 24.

4s The fact that federal legislation has been held to preempt the common law where the government files claims against interstate polluters may have operated to discourage some nuisance actions. Certainly federal legislation has, on its face, curtailed 
several defenses are available to alleged tortfeasors in these cases. When it is the federal government, rather than a private land-owner, that is seeking to have a neighboring nuisance abated, the neighbor is likely to raise the objection that such governmental action is inappropriate.

For example, the defendants in County Board argued that the proposed federal regulation was an unwarranted extension of the federal police power and that to grant an order preventing the erection of the high-rise towers would constitute a "taking" prohibited by the fifth amendment. The court agreed: "To sustain such an interference with the use of private land without compensation as an exercise of the police power has been farther than the courts have been willing to go."'44 The equal protection clause furnishes another possible defense: the defendant can claim that the government's action constitutes discriminatory enforcement of federal statutes or regulations. ${ }^{45} \mathrm{~A}$ defense that has lost much of its persuasiveness in recent years is the argument that the government's attempted regulation of the nuisance exceeds the powers conferred under the property clause. ${ }^{46}$

Despite the availability of these defenses, the longstanding federal common law of nuisance exists as a potential check against the proliferation of harmful developments outside park borders. Although their value cannot be objectively proved, such suits and the threat of such suits in all probability deter those who own property adjacent to the parks from initiating detrimental activities. At the very least, the potential for such suits may encourage private property owners to discuss

the scope of federal nuisance law; it may be, however, that all the legislation has simply done is shift the basis for enjoining nuisances from the common law to statutes.

14487 F. Supp. at 143. The court pointed to another possible limitation on the effectiveness of nuisance actions for protecting parks when it asserted that "[u]nsightliness or offense to the esthetic senses is not sufficient to constitute a public nuisance." Id. at 143. The Supreme Court, however, has spoken out somewhat differently on this question. In a case discussing standing to challenge the Secretary of the Interior's alleged failure to prevent interference with a national park, the Court said that "[a]esthetic and environmental well-being, like economic well-being, are important ingredients of the quality of life in our society, and the fact that particular environmental interests are shared by the many rather than the few does not make them less deserving of legal protection through the judicial process." Sierra Club v. Morton, 405 U.S. 727, 734 (1972). See also Note, Aesthetic Nuisance: An Emerging Cause of Action, 45 N.Y.U. L. REv. 1075 (1970) (arguing for acceptance and expansion of the cause of action).

15 See, e.g., United States v. Stoeco Homes, Inc., 359 F. Supp. 672, 678 (D.N.J. 1973) vacated on other grounds and remanded with instructions to modify the injunction, 498 F.2d 597 (3d Cir. 1974), cert. denied, 420 U.S. 927 (1975).

16 For a discussion of the claim that government is exceeding its power under the property clause, see Note, The Property Power, Federalism, and the Equal Footing Doctrine, 80 Colum. L. Rev. 817 (1980). But see Kleppe v. New Mexico, 426 U.S. 529 (1976) (interpreting Congress's power under the property clause broadly). See generally infra notes 80-89 and accompanying text. 
their planned activities with government officials, and discussions may lead to a mutually satisfactory solution.77 The limited usefulness of the nuisance doctrine in preserving the national parks may therefore be more the result of failure to assert it than of any inherent shortcomings in the doctrine.

\section{B. The Public Trust Doctrine}

This section briefly reviews the extent to which courts have recognized duties imposed upon the federal government and its agencies as trustees of the national parks. Whereas courts have been quite willing to recognize the federal government as a trustee of the public lands, they have been less willing to rule that this trusteeship imposes affirmative duties on federal officials. This judicial reticence has limited the effectiveness of the public trust doctrine as a tool for combating external threats to the national parks.

The public trust doctrine holds that the federal government maintains the public lands in trust for the people of the United States and that congressional authority to protect or dispose of these lands is judicially unreviewable. ${ }^{48}$ Courts have indicated that they accept the doctrine. For example, in an 1897 case, Camfield $v$. United States, ${ }^{48}$ a landowner had erected a system of fences on private lands, effectively enclosing over twenty thousand acres of federal public lands. In upholding a congressional act prohibiting such enclosures of federal land, the Supreme Court stated that the federal government "would be recreant to its duties as trustee for the people of the United States to permit any individual or private corporation to monopolize [public lands] for private gain ...." Tho This notion of a public trusteeship was adverted

17 For example, in Commonwealth v. National Gettysburg Battlefield Tower, Inc., $454 \mathrm{~Pa}$. 193, 311 A.2d 588 (1973), the private developers went to the National Park Service with a proposal for the placement of the observation tower. The Park Service indicated that the site initially proposed was problematic and later approved the site where the tower was actually constructed. $454 \mathrm{~Pa}$. at $195,311 \mathrm{~A} .2 \mathrm{~d}$ at 589 .

18 Light v. United States, 220 U.S. 523, 537 (1911). As Justice Reed said in Alabama v. Texas, 347 U.S. 272 (1954),

The United States holds resources and territory in trust for its citizens in one sense, but not in the sense that a private trustee holds for a cestui que trust. The responsibility of Congress is to utilize the assets that come into its hands as sovereign in the way that it decides is best for the future of the Nation . . . . Such congressional determination as the legislation here in question is not subject to judicial review.

Id. at 277 (Reed, J., concurring).

10167 U.S. 518 (1897).

${ }^{\text {so }}$ Id. at 524 . 
to more recently in United States $v$. Curtis-Nevada Mines, Inc. ${ }^{51}$ In that case, the government sued a mining company that was restricting access to a national forest adjacent to the public lands the company had been licensed to mine. In granting the government's request for a court order barring such restrictions, the court noted that "historically the United States has managed the lands within the public domain as fee owner and trustee for the people of the United States." "32

During the 1970's, the public trust doctrine received a great deal of attention from commentators, who argued that the doctrine imposed affirmative duties on government officials. Beginning with Professor Sax in $1970,{ }^{53}$ a number of commentators insisted that the public trust concept ought to be a means for concerned individuals to challenge in court the way in which federal agencies and officials manage the public lands. ${ }^{54}$ In 1974, a federal court accepted those arguments.

In that case, Sierra Club v. Department of the Interior, ${ }^{\text {,5 }}$ the plaintiff environmentalist group alleged that the Secretary of the Interior was failing to protect the Redwood National Park in California and thus breaching his duties as public trustee of the park. The threats to the park's well-being came from private lumber companies, which retained ownership of much of the land surrounding the park. ${ }^{56}$ Extensive lumbering activities conducted on the companies' lands were creating significant problems of improper water drainage and soil erosion within the park. ${ }^{87}$ The court denied the Secretary's motion to dismiss the case, and ruled that the National Park Service Organic Act ${ }^{58}$ and the Redwood National Park Act ${ }^{59}$ impose affirmative duties upon the

s1 611 F.2d 1277 (9th Cir. 1980).

62 Id. at 1283.

s3 Sax, The Public Trust Doctrine In Natural Resource Law: Effective Judicial Intervention, 68 Mich. L. REv. 471 (1970).

st See, e.g., Cohen, The Constitution, the Public Trust Doctrine, and the Environment, 1970 UtaH L. REv. 388; Stone, Should Trees Have Standing?-Toward Legal Rights For Natural Objects, 45 S. Gal. L. Rev. 450 (1972); Wilkinson, The Public Trust Doctrine in Public Land Law, 14 U.G.D. L. REv. 269 (1980); Note, Proprietary Duties of the Federal Government Under the Public Land Trust, 75 Mich. L. Rev. 586 (1977). Without using the term "public trust," Justice Douglas indicated agreement with the public trust approach to environmental protection. Sierra Club v. Morton, 405 U.S. 727, 741-52 (1972) (Douglas, J., dissenting).

ss 376 F. Supp. 90 (N.D. Cal. 1974).

so Before Sierra Club brought suit, the Department of the Interior had attempted to remedy the situation by preparing a report on the "threatened and actual damage" to the park and by requesting voluntary cooperation from the adjacent companies. Id. at 92 .

${ }^{87}$ Id. at 92-93.

s8 In construing the Act, the court relied on 16 U.S.C. $\S 1$ (1970).

69 In construing the Act, the court relied on 16 U.S.C. $\$ \S 79 b(a), 79 c(d), 79 c(e)$ (1970). 
Secretary to act as trustee of the nation's parks. In its subsequent decision on the merits, the court concluded that "the defendants unreasonably, arbitrarily and in abuse of discretion, have failed, refused and neglected to take steps to exercise and perform duties imposed upon them" by those statutes. ${ }^{60}$

Within a few years of the Redwood Park litigation, however, a different federal court concluded, in Sierra Club v. Andrus ${ }^{\mathbf{6 1}}$ that the National Park Service Organic Act ${ }^{62}$ did not impose any special "trustee" duties upon the Secretary of the Interior. Relying on the Redwood Park case, the Sierra Club contested the Secretary's decision not to interfere with the construction in northern Arizona and southern Utah of energy projects that would disrupt waters flowing through Grand Canyon National Park and other public lands. The court ruled in favor of the Secretary, holding that his decision not to assert federal water rights in the area had a "rational basis." In rebutting the plaintiff"s claim that the National Park Service Organic Act imposed special trustee duties upon the Secretary, the court stated: "To the extent that plaintiff's argument advances the proposition that defendants are charged with 'trust' duties distinguishable from their statutory duties, the Court disagrees. Rather, the Court views the statutory duties previously discussed as comprising all the responsibilities which defendants must

00 Sierra Club v. Department of the Interior, 398 F. Supp. 284, 293 (N.D. Cal. 1975). Pursuant to the court's decision, the Secretary took the following steps: he petitioned the Office of Management and Budget for money to acquire more buffer-zone protection; he requested legislative authority to regulate outside the park boundaries; he asked the private companies to comply with guidelines; he asked California to take regulatory measures; and he requested the Justice Department to sue the timber companies. The district court held that by taking these steps, the Department of the Interior had "in good faith and to the best of its ability" complied with the court's earlier order. Sierra Club v. Department of the Interior, 424 F. Supp. 172, 175 (N.D. Cal. 1976).

61487 F. Supp. 443 (D.D.C. 1980). The Sierra Club took a narrow appeal from the district court's judgment, challenging only the court's decision not to rule upon whether the Lands Policy Act confers by implication certain federal reserved water rights. The court of appeals upheld the district court. Sierra Club v. Watt, 659 F.2d 203, 206 (D.C. Cir. 1981).

22 Subsequent to the Redwood Park litigation, the relevant section of the National Park Service Organic Act was amended, with the following language added:

The authorization of activities shall be construed and the protection, management, and administration of these areas shall be conducted in light of the high public value and integrity of the National Park System and shall not be exercised in derogation of the values and purposes for which these various areas have been established.

Act of Mar. 27, 1978, Pub. L. No. 95-250, § 101(b), 92 Stat. 163, 166 (1980) (codified at 16 U.S.C. § 1a-1 (1982)).

es 487 F. Supp. at 450 . 
faithfully discharge."

As the Redwood Park and Andrus cases indicate, the chief disadvantage of the public trust doctrine is that its application' depends upon judicial interpretation of vague statutory language. ${ }^{65}$ Because of statutory imprecision, courts are free to find or not to find affirmative trustee duties as they see fit. Since primary responsibility for maintaining public lands rests with Congress, ${ }^{66}$ the simplest way to strengthen the public trust doctrine would be for Congress explicitly to impose trustee duties upon the Secretary in park enabling statutes.

Such a solution may not be politically feasible, however. Many of the western states, in which federal lands constitute a significant percentage of the total acreage, fear that imposing specific preservationist duties upon the Secretary will prevent economic development in their states. ${ }^{67}$ Indeed, one commentator has argued that the federal government no longer has any trustee authority over public lands in the western states: "There can be little doubt that a trust was in fact created at the time of the original cessions of western lands under the Confederation. However, the states placed the lands in trust only until the area could be formed into new and independent states."

Despite the obstacles to developing the public trust doctrine into a viable tool for preserving national parks, commentators continue to assert that the doctrine can play an effective role. ${ }^{69}$ Even if Congress fails to make the trustee duties explicit, courts remain free to infer such duties from existing statutes. A recent commentator has stated that "the

64 Id. at 449. The court based its decision on a review of the legislative history of the 1978 amendments to the National Park Service Organic Act. See supra note 62 and accompanying text. For a critique of this decision, see Wilkinson, supra note 54, at 290-93. For a brief discussion of the Redwood Park and Andrus cases, see Tarlock, supra note 16 , at 268-69.

os Another problem with the doctrine is uncertainty about exactly what duties public trusteeship entails. In Andrus, the court refused to find any special trustee duties, holding that the Secretary's decision whether to assert federal water rights need only have a "rational basis." 487 F. Supp. at 450 . See also supra text accompanying note 63. If the Andrus court had interpreted the statute to include special trustee duties, it is not at all clear what those duties would have been.

${ }_{68}$ See U.S. ConsT. art. IV, $\S 3$, cl. 2; see also supra note 48 and accompanying text.

${ }^{67}$ In recent congressional debates over a bill that would increase the Secretary's responsibilities to preserve parks, many representatives from western states argued that the bill would operate to the detriment of economic growth in their states. See infra notes 125-26 and text accompanying notes 125-29.

${ }^{68}$ Brodie, A Question of Enumerated Powers: Constitutional Issues Surrounding Federal Ownership of the Public Lands, 12 PAc. L.J. 693, 704 (1981) (footnote omitted).

${ }_{60}$ See, e.g., The Public Trust Doctrine in Natural Resources Law and Management: A Symposium, 14 U.C.D. L. REv. 181 (1980) (papers by Professor Sax, Professor Wilkinson, Deputy Attorney General Stevens, and others). 
fact that the public trust doctrine in public land law must rest on implication should surprise no one. The doctrine has always rested on implication."70 This implication, he argues, is supported by recent legislation that reflects a national interest in preserving and prudently managing our public resources. Perhaps continuing encroachments on our national parks will impel courts to accept and impose this implied public trust.

\section{Legislative Responses and Potentials}

Since solving the problems posed by threats external to national parks through reliance on the nuisance and public trust doctrines has proved only partially successful, it is important to examine existing and potential legislative responses to the parks' problems. This part first discusses the limited usefulness of federal statutes enacted to combat threats to specific national wildlife and parks. A pending bill, H.R. 2379 , which is designed to identify and eliminate threats to the national parks, is then discussed and critiqued.

\section{A. Existing Legislative Responses}

In 1916, Gongress enacted legislation establishing the National Park Service. ${ }^{71}$ That statute provides that the purpose of the Park Service is "to conserve the scenery and the natural and historic objects and the wild life therein" and to "leave them unimpaired for the enjoyment of future generations." ${ }^{.72}$ In 1978, Congress supplemented this section concerning the purposes of the Park Service and insisted that

[ $t$ ] he authorization of activities shall be construed and the protection, management, and administration of these areas shall be conducted in light of the high public value and integrity of the National Park System and shall not be exercised in derogation of the values and purposes for which these various areas have been established. ${ }^{73}$

Although somewhat rhetorical, this statement manifests Congress's intent that preservation of the national parks be a primary concern of the Park Service. Thus, when developments bordering on the parks threaten them, the Park Service is responsible for taking measures to ensure that the developments do not intrude upon the parks. Despite

70 Wilkinson, supra note 54 , at 299.

${ }^{71} \S 1,39$ Stat. 535 (1916) (codified as amended at 16 U.S.C. $\S \S 1-20 \mathrm{~g}(1982)$ ).

7216 U.S.C. $\$ 1$ (1982).

73 Id. $\$ 1 \mathrm{a}-1$. 
this congressional mandate, park officials have never attempted to regulate developments on park borderlands solely on the basis of these statutory passages.

Federal officials have, however, taken measures to affect such private behavior on nonfederal lands pursuant to authority vested in them by other federal legislation. Federal interference with the activities of private parties most commonly occurs where Congress authorizes acquisition of adjoining private lands, the proposed development of which "could significantly damage the park resources or is incompatible with park values." "74 Since many of the park enabling statutes include sections setting forth explicit guidelines for acquiring private lands, ${ }^{76}$ land acquisition has proven an important means for protecting parks from their neighbors. ${ }^{76}$ As suggested previously, however, park preservation through land acquisition is unsatisfactory in the long run ${ }^{77}$ for reasons such as cost. ${ }^{78}$ Two other legislatively authorized measures for protecting federal interests from adverse private activities deserve special attention. ${ }^{79}$

74 National. Park Serv., U.S. DeP'T of the Interior, Management PoliCIES IX-1 (1978), quoted in Lambert, supra note 11, at 36 .

${ }_{70}$ The enabling statutes of parks created after 1959 generally contain detailed procedures and express grants of authority for additional land acquisitions. See Lambert, supra note 11, at 36-37. The National Park Service has developed its own programs and procedures for acquiring lands in and around parks created before 1959. Id.

${ }^{26}$ See supra note 10 and accompanying text.

77 See supra notes 11-12 and accompanying text.

78 Between 1965 and 1977 , the National Park Service spent $\$ 815$ million to purchase nearly one million acres of land from over 45,000 property owners. UNITED States Gen. Accounting Off., The Federal Drive to Acquire Private LANDS Should BE ReAsSessed 9 (1979), cited in Lambert, supra note 11, at $36 \mathrm{n} .8$.

${ }^{79}$ Two less recent examples of such measures should be mentioned. In Camfield v. United States, 167 U.S. 518 (1897), the Court upheld the constitutionality of a federal statute that prohibited the enclosure of public lands by private individuals. The defendants had enclosed over 20,000 acres of federal lands through the erection of an "ingenious" scheme of fences on their own property. Id. at 525. In upholding a lower court's order that the defendants remove the fences, the Court stated,

Considering the obvious purposes of this structure, and the necessities of preventing the enclosure of public lands, we think the fence is clearly a nuisance, and that it is within the constitutional power of Congress to order its abatement, notwithstanding such action may involve an entry upon the lands of a private individual.

Id. The Court noted that had the fences been erected directly on the federal property the government could have removed them without relying upon the statute but that the statute was important in the existing situation since the fences were on private lands. Id. at 524-25.

United States v. Alford, 274 U.S. 264 (1927), involved a federal statute that imposed criminal liability on those who build and fail to extinguish fires near public lands. Alford asserted that the statute could not constitutionally reach him since his fire was situated on private land. Justice Holmes, writing for the majority, did not agree: "The danger depends upon the nearness of the fire, not upon the ownership of the land 
The Wild Free-Roaming Horses and Burros Act ${ }^{80}$ was passed by Congress in 1971 to protect "all unbranded and unclaimed horses and burros on public lands of the United States"81 from "capture, branding, harassment, or death."82 The Act authorizes the Secretaries of the Interior and Agriculture to "enter into cooperative agreements with other landowners and with the State and local governmental agencies and ... issue such regulations as . . . [are] necessary for the furtherance of the purposes of this chapter." ${ }^{\text {"83 }}$ In Kleppe v. New Mexico, ${ }^{84}$ the Supreme Court upheld the constitutionality of the Act in a unanimous decision that has far-reaching implications for the authority of Congress to protect public lands and interests from the activities of neighboring private property owners.

The controversy in Kleppe arose after a local rancher requested that the New Mexico Livestock Board remove a number of burros that were interfering with his cattle. ${ }^{85}$ After the burros were captured and auctioned off, the Secretary of the Interior sought to have the Livestock Board recover and return the burros. In response, New Mexico brought suit for a declaration that the Act was unconstitutional.

In a sweeping opinion, the Court held that when acting pursuant to the property clause of the Constitution, ${ }^{86}$ "the power over the public land thus entrusted to Congress is without limitations." ${ }^{\text {"8z }}$ Further, the Court held that federal legislation regarding the public lands will prevail over conflicting state law. ${ }^{\mathbf{8}}$ The opinion, not surprisingly, has

where it is built. . . . Congress may prohibit the doing of acts upon privately owned lands that imperil the publicly owned forests." Id. at 267.

so 16 U.S.C. $\S \S 1331-1340$ (1982).

81 Id. \& 1332(b).

82 Id. $\$ 1331$.

${ }^{83}$ Id. $\S 1336$.

84426 U.S. 529 (1976).

${ }^{85}$ The Bureau of Land Management had previously denied the rancher's request to remove the burros. The land itself was federal and was being leased to the rancher for grazing purposes. 426 U.S. at 533.

${ }_{86}$ The property clause, U.S. CoNST. art. IV, § 3, cl. 2, states that "Congress shall have Power to dispose of and make all needful Rules and Regulations respecting the Territory or other Property belonging to the United States ....."

87426 U.S. at 539 (quoting United States v. San Francisco, 310 U.S. 16, 29 (1940)).

88 But while Congress can acquire exclusive or partial jurisdiction over lands within a State by the State's consent or cession, the presence or absence of such jurisdiction has nothing to do with Congress ${ }^{3}$ powers under the Property Clause. Absent consent or cession a State undoubtedly retains jurisdiction over federal lands within its territory, but Congress equally surely retains the power to enact legislation respecting those lands pursuant to the Property Clause. . . . "A different rule would place the public domain of the United States completely at the mercy of state legislation." 
sparked a good deal of debate over its expansive interpretation of the property clause and the implications thereof. ${ }^{89}$ Nevertheless, the Supreme Court clearly interprets the Constitution as granting Congress wide power to care for the public lands. ${ }^{80}$

A similar example of congressional action regulating the use of private lands in order to protect federal interests is the Boundary Waters Canoe Area Wilderness Act ${ }^{81}$ (BWCAWA) of 1978. In Minnesota ex rel. Alexander $v$. Block, ${ }^{92}$ the Court of Appeals for the Eighth Gircuit upheld the portions of the Act limiting the use of motorized vehicles in the wilderness area. ${ }^{83}$ The United States owned ninety percent of the land within the designated wilderness area, and the state of Minnesota owned most of the remaining ten percent. ${ }^{84}$ In upholding Congress's authority to limit motorized vehicles throughout the entire wilderness area, the court of appeals, relying heavily on Kleppe, ${ }^{95}$ stated,

Under the authority conferred by the property clause to protect the public land, Congress' power must extend to reg- . ulation of conduct on or off the public land that would threaten the designated purpose of federal lands. Congress clearly has the power to dedicate federal land for particular

citations omitted). See also supra note 79 . One of the arguments raised by New Mexico in Kleppe was that the Livestock Board's action of rounding up and auctioning off the burros was valid since the Board acted pursuant to the New Mexico Estray Law, N.M. Stat. ANN. § 47-14-1 (1966) (codified as amended at N.M. STAT. ANN. §§ 7713-1 to 77-13-10 (1978)). See 426 U.S. at 533, 541-46.

${ }_{89}$ See, e.g., Engdahl, State And Federal Power Over Federal Property, 18 ARIz. L. REv. 283, 348-58, 369-71 (1976); Gaetke, Congressional Discretion Under the Property Clause, 33 Hastings L.J. 381 (1981); Note, supra note 46.

${ }_{80}$ The opinion did not accord Congress limitless power. The Court said that "the furthest reaches of the power granted by the Property Clause have not yet been definitively resolved." 426 U.S. at 539. Consequently, the Court decided to "leave open the question of the permissible reach of the Act over private lands under the Property Clause." Id. at 547.

${ }^{91}$ Pub. L. No. 95-495, 92 Stat. 1649-59 (1978). The Boundary Waters Canoe Area Wilderness appears in the tabular listing of official wilderness areas at 16 U.S.C. $\S 1132(1982)$.

${ }_{92} 660$ F.2d 1240 (8th Cir. 1981), cert. denied, 455 U.S. 1007 (1982).

9s See id. at 1246-47 n.9 (upholding BWCAWA $\S 4(\mathrm{c})$, (e), (f), (i), 92 Stat. 1649, 1650-52). Section 4(i) of the law states in part: "Except for motorboats, snowmobiles, and mechanized portaging, as authorized and defined herein, no other motorized use of the wilderness shall be permitted." BWCAWA $\S 4(i), 92$ Stat. at 1652.

94660 F.2d at 1244.

9s The Block court, for example, quoted Kleppe's statement that "the furthest reaches of the power granted by the Property Clause have not yet been definitively resolved" but that "the power over the public lands thus entrusted to Congress is without limitations," "Kleppe, 426 U.S. at 539, quoted in Block, 660 F.2d at 1248. The Block court then concluded that "with this guidance, we must decide the question left open in Kleppe-the scope of Congress's property clause power as applied to activity occurring off federal land." Block, 660 F.2d at 1248. 
purposes. As a necessary incident of that power, Congress must have the ability to ensure that these lands be protected against interference with their intended purposes. ${ }^{98}$

Further, the court rejected the appellants' argument that the tenth amendment to the Constitution ${ }^{87}$ barred the application of Congress's motorized vehicle restrictions to land and waters under state jurisdiction. ${ }^{98}$ As in Kleppe, the court's position here is quite clear: Congress has broad authority under the property clause to protect public lands from private activities. ${ }^{99}$

Although these examples indicate that the federal government has the constitutional authority to protect its interests and lands through provisions in specific legislation, this is not to say that the method is a desirable one for the more general problem of protecting national parks from outside encroachments. As the BWCAWA example indicates, to be effective, such an approach might require a great deal of specificity. Section $4(c)$ of that act, for example, is devoted to a detailed listing of various lakes and waterways and the horsepower limitations on motorboats using those lakes. ${ }^{100}$ With all its specificity, BWCAWA alone is insufficient to address or anticipate all the problems that face that wilderness area. ${ }^{101}$

To require that Congress first identify and then rectify through

${ }^{86} 660$ F.2d at 1249 (footnote omitted).

97 "The powers not delegated to the United States by the Constitution, nor prohibited by it to the States, are reserved to the States respectively, or to the people." U.S. Const. amend. X.

${ }_{98}$ The court used the test articulated by the Supreme Court in Hodel v. Virginia Surface Mining \& Reclamation Ass'n, Inc., 452 U.S. 264 (1981), as the one properly to be applied in tenth amendment challenges brought under the rationale of National League of Cities v. Usery, 426 U.S. 833 (1976). The court held that appellants' argument failed under the first part of the Virginia Surface Mining test: $\S 4$ of the BWCAWA does not regulate the "States as States." Block, 660 F.2d at 1251-52.

In another group of appeals considered in the same opinion, the Block court rejected challenges to $\S 5$ of the BWCAWA, which gives the United States a right of first refusal with respect to certain property in the area. 92 Stat. at 1652 . The court held that $\S 5$ did not amount to an unconstitutional taking by the government, and that it did not deprive private citizens of their property rights without due process of law. 660 F.2d at $1255-56$.

${ }^{29}$ See also United States v. Lindsey, 595 F.2d 5, 6 (9th Gir. 1979) (ruling that the Secretary of Agriculture can regulate against camping and campfires on state lands surrounded by National Forests: "It is well established that this [property] clause grants to the United States power to regulate conduct on non-federal land when reasonably necessary to protect adjacent federal property or navigable waters").

100 BWCAWA \& 4(c), 92 Stat. at 1650-51.

101 That Congress was aware that the Act could not handle all possible situations is evident by $\S 15$ of the Act: "The Secretary [of Agriculture] is authorized to promulgate and enforce regulations that limit or prohibit the use of motorized equipment on or relating to waters located within the wilderness in accordance with the provisions of this Act." Id. § 15, 92 Stat. at 1657. 
specific, extensive legislation all the threats facing each national park area would be to impose an exhausting if not impossible chore. Glearly, a more efficient and comprehensive approach is needed for dealing with the threats facing our national parks.

\section{B. H.R. 2379: A Systematic But Insufficient Approach}

That Congress has begun to recognize the need for a systematic, comprehensive approach to the serious problems confronting the national parks is demonstrated by the recent passage of H.R. $2379^{102}$ by the House of Representatives. ${ }^{103}$ The purpose of the bill, entitled the "National Park System Protection and Resources Management Act of $1983, " 104$ is "to provide for a high degree of protection and preservation of the natural and cultural resources within the national park system." ${ }^{\text {"10s }}$ Despite this laudable goal, H.R. 2379 fails to provide a viable mechanism for ensuring lasting protection of the national parks from external threats.

H.R. 2379 was developed in response to a 1980 National Park Service survey that detailed over four thousand individual threats to the various parks. ${ }^{106}$ The Committee on Interior and Insular Affairs, to which the bill was referred upon introduction, ${ }^{107}$ concluded that more

${ }^{102}$ H.R. 2379, 98th Cong., 1st Sess. (1983). The bill was amended several times on the floor of the House before it was passed. The bill, as passed by the House, can be found at 129 CoNG. REC. H7914-17 (amendment in the nature of a substitute offered by Rep. Udall), H7917-18 (amendment offered by Rep. Seiberling to the amendment in the nature of a substitute offered by Rep. Udall), H7931 (amendment offered by Rep. Murphy to the amendment in the nature of a substitute offered by Rep. Udall, as amended), H7932 (amendment offered by Rep. Brown of Colorado to the amendment in the nature of a substitute offered by Rep. Udall, as amended), and H7933 (amendment offered by Rep. Seiberling to the amendment in the nature of a substitute offered by Rep. Udall, as amended) (daily ed. Oct. 4, 1983).

103 The bill passed the House on October 4, 1983. 129 Cong. REC. H7934 (daily ed. Oct. 4, 1983). The bill was then referred to the Senate Committee on Energy and Natural Resources, which has yet to report the bill to the full Senate. Id. at S13,767 (daily ed. Oct. 6, 1983).

During the second session of the 97th Congress, H.R. 5162, which was virtually identical to H.R. 2379, passed the House but was never reported to the full Senate for debate. 128 Cong. Rec. at H7914 (daily ed. Sept. 29, 1982).

104 H.R. 2379, 98th Cong., 1st Sess. $§ 1,129$ CoNG. REC. H7914 (daily ed. Oct. 4,1983 ) (for the bill in its entirety as amended, see supra note 102).

${ }_{105}$ Id. § 3, 129 CoNG. REC. H7914 (daily ed. Oct. 4, 1983).

${ }^{108} 129$ CoNG. Rec. H7869 (daily ed. Oct. 3, 1983). The survey was completed at the request of the Committee on Interior and Insular Affairs, and was conducted by asking each park superintendent to detail the nature and source of each threat to the park.

${ }^{107}$ The bill was introduced by Representative John F. Seiberling of Ohio and 85 cosponsors on March 24, 1983. Id. at $\mathrm{H} 1809$ (daily ed. Mar. 24, 1983). Representative Seiberling serves as chairman of the Subcommittee on Public Lands and National Parks. See id. at H7869 (daily ed. Oct. 3, 1983) (statement of Rep. Seiberling). 
than fifty percent of those threats were attributable to sources external to the parks. ${ }^{108}$ Those who drafted H.R. 2379 developed four key provisions that may aid in confronting existing and future external threats to the parks.

First, the bill requires the Secretary of the Interior to submit a "state of the parks" report to Congress every two years. ${ }^{109}$ Among other things, the report must describe "the impact from identified factors and forces, ranked in order of priority, emanating from both inside and outside the unit, that damage or threaten to damage" each of the national parks. ${ }^{110}$ The report must also assess the existing and potential legal authority for. dealing with these threats. ${ }^{111}$

Second, in a report submitted annually to Congress, the Secretary must "identify and establish priorities among at least the fifty most critical" natural and cultural resource problems within the park system. ${ }^{112}$ This list "should constitute the systemwide priority problems emanating from outside, as well as inside the parks."113

Third, in the case of areas "adjacent to any unit of the national park system"114 where the Secretary has existing authority to issue a lease, grant a permit, or dispose of federal resources, the Secretary must determine if exercising that authority will have a "significant adverse effect"115 on the "values for which the national park system was established."116 The Secretary must decline to exercise that authority if the "public interest in preventing such adverse effect on such values signifi-

108 H.R. ReP. No. 170, supra note 4, at 3; see also 129 Cong. Rec. H7869 (daily ed. Oct. 3, 1983) (statement of Rep. Seiberling).

109 H.R. 2379, 98th Cong., 1st Sess. § 4, 129 CoNG. Rec. H7914 (daily ed. Oct. 4,1983 ) (for the bill in its entirety as amended, see supra note 102).

${ }_{110}$ Id. $\S 4(\mathrm{a})(1)(\mathrm{B}), 129$ CoNG. REC. H7914 (daily ed. Oct. 4, 1983).

111 Id. \& 4(a)(3)(F), 129 CoNG. Rec. H7914 (daily ed. Oct. 4, 1983).

112 Id. $\S 5,129$ Cong. REc. H7915 (daily ed. Oct. 4, 1983) (emphasis omitted).

113 H.R. REP. No. 170, supra note 4, at 5.

114 Much debate in committee focused on defining "adjacent to." One amendment that was adopted but subsequently dropped by the committee defined the term as nearby and not in excess of ten miles from the park boundary. See H.R. REP. No. 170, supra note 4, at 11 . The issue of defining "adjacent to" was also raised several times during the House debate. See, e.g., 129 Cong. Rec. H7871 (daily ed. Oct. 3, 1983) (statement of Rep. Lujan); id. at H7873 (statement of Rep. Hansen); id. at H7875 (statement of Rep. Nielson).

115 H.R. 2379, 98th Cong., 1st Sess. § 10(b), 129 Cong. REc. H7917 (daily ed. Oct. 4, 1983). Some members of Congress were troubled that the term "significant adverse effect" was not defined in the bill. As one representative asked, "Does a little dust being raised by a car, or by a horse, a cow or whatever, in the vicinity, is that a significant action before going to lease that land for grazing?" 129 CoNG. REC. H7873 (daily ed. Oct. 3, 1983) (statement of Rep. Lujan).

116 H.R. 2379, 98th Cong., 1st Sess. § 10(b), 129 Cong. Rec. H7917 (daily ed. Oct. 4,1983 ) (for the bill in its entirety as amended, see supra note 102). 
cantly outweighs the public interest value of the proposed action."117

Finally, in what has been described as the "most objectionable part" of the bill, ${ }^{118}$ H.R. 2379 requires all federal agencies contemplating action within or adjacent to a national park to inform the Secretary of such proposed action whenever there is a possibility of a "significant adverse effect" on the park. ${ }^{110}$ The Secretary must respond to the agency within sixty days with comments and recommendations for changes in the proposed action, if necessary. ${ }^{120}$

Although H.R. 2379 passed the House by a margin of almost four-to-one, ${ }^{\mathbf{1 2 1}}$ the bill met with stiff opposition from several sources on various grounds. Several members of Congress, for example, doubted the reliability of the 1980 National Park Service survey that prompted the bill. ${ }^{122}$ Both the National Park Service ${ }^{123}$ and the Department of the Interior ${ }^{124}$ contended that the bill was unnecessary and imposed

117 Id. The Secretary is also required to publish the record of his decision in the Federal Register and transmit copies of the "decision documents" to the Senate Committee on Energy and Natural Resources and the House Committee on Interior and Insular Affairs. Id.

118 H.R. REP. No. 170, supra note 4, at 20 (dissenting views). During the House debate, one representative, who had been among the three members of the Committee on Interior and Insular Affairs who dissented to the committee's report on H.R. 2379, stated, "[S]ection $11 \mathrm{I}$ think is one of the most devastating things I have seen come along for a long time." 129 CoNG. REC. H7873 (daily ed. Oct. 3, 1983) (statement of Rep. Hansen).

11 H.R. 2379, 98th Cong., 1st Sess. § 11, 129 CoNG. REc. H7917-18 (daily ed. Oct. 4, 1983) (for the bill in its entirety as amended, see supra note 102).

120 Id. § 11(c), 129 CoNG. REc. H7917-18 (daily ed. Oct. 4, 1983). If the proposed action will occur "within" one of the parks, the sister agency cannot proceed until the Secretary approves the action. If the proposed action will occur "adjacent to" national park land, the sister agency is free to ignore the Secretary's recommendations. See id. §11(e), 129 CoNG. REc. H7918 (daily ed. Oct. 4, 1983).

121 The recorded vote was 321 "yeas" and 82 "nays," with 30 not voting. 129 ConG. REC. H7934 (daily ed. Oct. 4, 1983). Interestingly, H.R. 5162, the predecessor to H.R. 2379, was introduced during the second session of the 97th Congress and passed the House by a recorded vote of 319 "yeas" to 84 "nays." 128 id. at H7914 (daily ed. Sept. 29, 1982).

132 The dissenting members of the Committee on Interior and Insular Affairs called the survey a "woefully inadequate and hastily-prepared document." H.R. REP. No. 170, supra note 4, at 17. See also 129 CoNG. REc. H7872 (daily ed. Oct. 3, 1983) (statement of Rep. Hansen). Even Representative Seiberling, who introduced the bill, referred to the survey as "somewhat of a subjective study." Id. at $\mathrm{H} 7869$.

${ }^{123}$ Mr. Russell Dickenson, Director of the National Park Service, testified during the subcommittee hearings on H.R. 2379, and part of his testimony was quoted during the House debate of the bill. Mr. Dickenson stated that the duties to be imposed on the Park Service and Secretary of the Interior by the bill were already part of their responsibilities, and that "essentially" he objected to H.R. 2379 because it made those responsibilities a statutory requirement. 129 CoNG. REc. H7870 (daily ed. Oct. 3, 1983) (statement of Rep. Seiberling).

124 "H.R. 2379 is unnecessary, duplicates existing laws and administrative programs, creates more red tape, and imposes inflexible requirements on resource management efforts that should remain flexible enough to apply available staff and funds to 
statutory duties in an area better handled through administrative discretion.

The most frequent criticism of the bill, however, was that it permitted federal interference with state and local interests. Representatives from the western states, where federal landholdings account for more than thirty percent of the land in ten states, ${ }^{125}$ feared that the bill would hinder economic growth by putting national park interests ahead of all others. ${ }^{126}$ For instance, a representative from Utah, noted that, if "adjacent to" were defined to mean within a ten-mile radius of the park, as some had suggested, ${ }^{127}$ the effect would be to "tie up, basically, all of southern and eastern Utah."128 The dissenting members of the House committee that reviewed the bill concluded:

[L]ocal and state governments, who through no fault of their own are located adjacent to national parks, should not be asked to sacrifice their growth and the economic well-being of their citizens because of perceived threats against park resources which emanate from beyond the borders of their neighboring parks without an adequate opportunity for input into the identification of, and amelioration of, any such perceived problems. ${ }^{129}$

It was probably this fear of excessive federal interference with local interests that caused the drafters of H.R. 2379 to create a toothless bill. In many respects, the responsibilities imposed upon the Secretary of the Interior by the bill are information-gathering duties: the Secretary must biennially catalogue and report to Congress the major inter-

changing needs. It attempts to impose statutory mandates on what are properly discretionary administrative functions." H.R. REP. No. 170, supra note 4, at $12-13$ (letter of Apr. 26, 1983, from Acting Assistant Secretary of the Interior J. Craig Potter to Committee on Interior and Insular Affairs Chairman Morris K. Udall).

125 See tables in Note, supra note 46 , at 817 n.1.

128 As summarized by one of the representatives from Oregon:

H.R. 2379 threatens community development, improvement projects, sewage treatment plants, road construction, and airports. This bill as currently drafted will also hinder mineral exploration, timber harvest, grazing, recreation, and other multiple uses in areas adjacent to national parks. These delays will certainly have a negative impact on jobs and the economies in communities adjacent to national parks.

129 Cong. Rec. H7876 (daily ed. Oct. 3, 1983) (statement of Rep. Smith).

127 See supra note 114 and text accompanying notes 114-17.

128129 Cong. Rec. H7875 (daily ed. Oct. 3, 1983) (statement of Rep. Nielson).

129 H.R. REP. No. 170, supra note 4, at 17-18. The dissenting members stated further, "Only by rolling the stone back over the crypt of Washington interference will local leaders and affected communities be afforded the autonomy they deserve." Id. at 20. 
nal and external threats facing the parks, ${ }^{130}$ and he or she must annually prioritize the fifty most critical such threats. ${ }^{131}$ Although the Secretary is required to assess the existing legal authority for handling these threats, ${ }^{132}$ he or she is given no new substantive authority for combating these threats. The House committee that reviewed and endorsed the bill stressed that

[a]lthough the point was discussed fully during the committee markup of the bill, it bears further clarification that the provisions of this bill do not provide either the Secretary or the National Park Service with any new authority to block or prohibit any project, action or initiative proposed by local, state, or Federal governmental units outside of park boundaries. ${ }^{133}$

With respect to private action on public lands adjacent to the national parks, the Secretary is permitted to deny the issuance of a lease or the grant of a permit where the proposed action may adversely affect the park. ${ }^{134}$ This authority, however, the Secretary already has. ${ }^{135} \mathrm{Re}-$ garding proposed action by other federal agencies, the "bill merely establishes a review and coordination mechanism to assure that all aspects of any Federal action's impacts on national park resources are fully considered."136 If the Secretary disapproves of the proposed action on land adjacent to the park, the sister agency is free to ignore the

1 so H.R. 2379, 98th Cong., 1st Sess. § 4, 129 Cong. Rec. H7914 (daily ed. Oct. 4,1983 ) (for the bill in its entirety as amended, see supra note 102); see also supra notes $109-11$ and accompanying text.

131 H.R. 2379, 98th Cong., 1st Sess. § 5, 129 Cong. Rec. H7915 (daily ed. Oct. 4, 1983) (for the bill in its entirety as amended, see supra note 102); see also supra notes $112-13$ and accompanying text.

132 H.R. 2379, 98th Cong., 1st Sess. § 4(a)(3)(F), 129 Cong. REc. H7914 (daily ed. Oct. 4, 1983) (for the bill in its entirety as amended, see supra note 102); see also supra note 111 and accompanying text.

133 H.R. REP. No. 170, supra note 4, at 10 (emphasis added). The representative who introduced the bill reiterated this observation during the House debate: "Truly, this is a modest bill. . . . It does not give the Secretary of the Interior, or anyone else, a veto over any Federal, State, local or private action-and I repeat that, it does not give anyone a veto over any Federal, State, or local or private action." 129 CoNG. REC. H7870 (daily ed. Oct. 3, 1983) (statement of Rep. Seiberling).

134 H.R. 2379, 98th Cong., 1st Sess. § 10(b), 129 CoNG. Rec. H7917 (daily ed. Oct. 4, 1983) (for the bill in its entirety as amended, see supra note 102); see also supra notes $114-17$ and accompanying text.

135 The language of the bill makes it clear that the provisions only apply where the Secretary already has power to act: "where the Secretary of the Interior is vested with any authority." H.R. 2379, 98th Cong., 1st Sess. $\$ 10($ a), (b), 129 CoNG. REc. H7917 (daily ed. Oct. 4, 1983) (emphasis added) (for the bill in its entirety as amended, see supra note 102).

196 H.R. REP. No. 170, supra note 4, at 10. 
Secretary's recommendation. ${ }^{\mathbf{1 3 z}}$

Thus, despite its laudatory objectives, H.R. 2379 falls far short of ensuring preservation of park resources. This bill provides for increased congressional awareness of threats to the parks without furnishing those in charge of the parks with any substantive authority for combating the threats. Not only does it fail to vest the Secretary with the requisite additional authority, but it also fails to establish a duty to address the threats with existing authority. For example, the bill ignores the whole realm of private nuisances on lands adjoining the parks, where such nuisances do not involve the issuance of a lease or the granting of a permit to use the park lands.

Clearly, more effective legislation is needed.

\section{A Proposal}

Praiseworthy objectives and numerous salutary provisions notwithstanding, H.R. 2379 is largely an ineffective response to the growing dangers posed by developments on lands adjacent to the national parks. A more effective response is legislation that retains the positive features of H.R. 2379 and then imposes upon the Secretary of the Interior a well-defined affirmative duty and the substantive authority to confront threats to the national parks from beyond their borders.

\section{A. Retaining Portions of H.R. 2379}

Probably the most salient feature of H.R. 2379 is that it provides a mechanism for communicating within the federal government the recognition of external threats to each of the national parks. The provisions establishing this mechanism should be retained and, in some circumstances, expanded.

For example, H.R. 2379 requires that the Secretary provide Congress with a biennial "state of the parks" report that details the various threats to each of the national parks and sets forth the past and proposed future action to counter those threats. ${ }^{138}$ This requirement of accountability to Congress should be retained. Included within this provi-

197 H.R. 2379, 98th Cong., 1st Sess. §11(e), 129 Cong. REc. H7918 (daily ed. Oct. 4,1983 ) (for the bill in its entirety as amended, see supra note 102). This section states that the Secretary's approval is required only when the proposed agency action will affect "[f]ederally owned lands or waters which are administered by the Secretary of the Interior and which are located within the authorized boundary of a National Park System unit." See supra note 120 and text accompanying notes 118-20.

${ }_{138}$ H.R. 2379, 98th Cong., 1st Sess. $§ 4,129$ CoNG. REC. H7914 (daily ed. Oct. 4,1983 ) (for the bill in its entirety as amended, see supra note 102); see also supra notes 109-11 and accompanying text. 
sion should be a requirement that the superintendents of each park regularly inform the Secretary of potential dangers to the park.

Similarly, H.R. 2379 requires the Secretary to submit to Congress an annual report that prioritizes the "fifty most critical" threats to the parks' natural and cultural resources. ${ }^{139}$ This provision should be amended to permit Congress to modify the Secretary's list of priorities. Permitting congressional modification provides the accountability mechanism necessary for ensuring that the Secretary's priorities do not reflect a strong pro-industry bias and that they accurately represent the true needs of the park system. ${ }^{140}$ Bias and inaccuracy have been a problem; House debates on H.R. 2379, for example, indicate that the bill was prompted, at least in part, by what many regarded as deliberate failure on the part of the incumbent Secretary of the Interior to protect the national parks. ${ }^{141}$

Finally, H.R. 2379 requires federal agencies to notify the Secretary when they contemplate any action on land adjacent to a national park that may adversely affect that park. ${ }^{142}$ The Secretary is then required to "make such comments and recommendations as he or she deems appropriate."143 Although this provision does not require the agency to abide by the Secretary's recommendations, ${ }^{144}$ the provision at

139 H.R. 2379, 98th Cong., 1st Sess. § 5, 129 CoNG. REC. H7915 (daily ed. Oct. 4,1983 ) (for the bill in its entirety as amended, see supra note 102); see also supra notes $112-13$ and accompanying text.

140 This "critical" list may also serve to define the contours of the standing requirement that is proposed in the following section. See infra note 162 and accompanying text.

${ }_{141}$ For example, during the House debates, the representative who introduced H.R. 2379 made the following remarks about then Secretary of the Interior James Watt when explaining why the bill must "spell out" the Secretary's duties to the national parks:

The gentlemen [Rep. Hansen of Utah] talked about zealous Secretaries of Interior. Certainly none is more zealous that [sic] the present incumbent. What his zeal is directed to is another question.

Certainly it is not directed to protecting the natural and cultural values in the national parks to the same degree as it is directed toward developing certain other types of resources, regardless of the consequences on the national park or other natural values.

So all I can say is if there ever was a reason for spelling it out we have that reason today, and that is in the demeanor and actions of the present Secretary.

129 Cong. Rec. H7921 (daily ed. Oct. 4, 1983) (statement of Rep. Seiberling).

142 H.R. 2379, 98th Cong., 1st Sess. § 11(a), 129 Cong. Rec. H7917 (daily ed.

Oct. 4, 1983) (for the bill in its entirety as amended, see supra note 102); see also supra notes $118-20$ and accompanying text.

143 H.R. 2379, 98th Cong., 1st Sess. § 11(b), 129 Cong. Rec. H7917 (daily ed.

Oct. 4,1983 ) (for the bill in its entirety as amended, see supra note 102).

${ }^{144}$ See supra notes 136-37 and accompanying text. Requiring the agency to abide by the Secretary's recommendations would, in effect, give the Secretary veto power over 
least requires both the agency and the Secretary to consider the proposed action's impact upon the park. Also, a copy of the Secretary's recommendations and the agency's ultimate decision must be submitted to the "appropriate committees of Congress,"146 which then have the power to initiate legislation to counteract a decision that may adversely affect a national park.

\section{B. Providing the Secretary with an Affirmative Duty and Substantive Authority}

Most of the provisions of H.R. 2379 that this proposal seeks to retain merely provide mechanisms for gathering and dispersing information about threats beyond the parks' borders. In order to animate these provisions, this proposal imposes upon the Secretary of the Interior an affirmative duty and the substantive authority to issue regulations for dealing with these external threats. In issuing regulations, the Secretary "must demonstrate a nexus between the regulated conduct and the federal land"146 and must establish "that the regulations are necessary to protect federal property." 147 Further, the regulations are to be issued in accordance with the procedures set forth in the Administrative Procedure Act (APA). ${ }^{148}$ Finally, private citizens and environmental groups shall have standing to challenge any alleged failure by the Secretary to carry out these duties.

As an initial matter, this delegation to the Secretary of the power to issue regulations that affect activities on private lands is constitutional. Congress's power, pursuant to the property clause, to protect federal lands extends to activities on private lands, according to the decisions in Kleppe v. New Mexico ${ }^{149}$ and Minnesota ex rel. Alexander v. Block. ${ }^{160}$ Although this power is not limitless, the court in Block noted that the exercise of the power would be constitutional if Congress could "demonstrate a nexus between the regulated conduct and the federal land, establishing that the regulations are necessary to protect federal

many of the activities of numerous federal agencies.

145 H.R. 2379, 98th Cong., 1st Sess. §11(c), 129 CoNG. REc. H7917-18 (daily

ed. Oct. 4, 1983) (for the bill in its entirety as amended, see supra note 102).

${ }^{146}$ Minnesota ex rel. Alexander v. Block, 660 F.2d 1240, 1249 n.18 (8th Cir. 1981), cert. denied, 455 U.S. 1007 (1982).

147 Id.

1485 U.S.C. $\S \S 551-706$ (1982).

149426 U.S. 529 (1976). "Camfield [v. United States, 167 U.S. 518 (1897)] contains no suggestion of any limitation on Congress' power over conduct on its own property; its sole message is that the power granted by the Property Clause is broad enough to reach beyond territorial limits." Id. at 538 . See supra notes $80,86,88,90,95 \& 100$ and text accompanying notes 80-99.

${ }^{150} 660$ F.2d 1240 (8th Cir. 1981), cert. denied, 455 U.S. 1007 (1982). 
property."151 Thus, since Congress has the power to monitor activities on private lands that adversely affect the national parks, the delegation of that power to the Secretary, provided that the Secretary demonstrates the requisite "nexus," would likewise be constitutional.

This proposal requires that the Secretary's regulations be issued in accordance with the procedures established in the APA. ${ }^{162}$ That act sets forth specific guidelines to be followed by agencies engaging in either rulemaking ${ }^{153}$ or adjudication, ${ }^{154}$ and it also prescribes the standard of judicial review of the agency action. ${ }^{155}$ The decision whether to proceed by rulemaking or adjudication is generally left to the discretion of the agency. ${ }^{158}$ This Comment, however, suggests that, if the Secretary of the Interior decides to issue regulations through rulemaking, he or she should be required to use "notice and comment" procedures. ${ }^{157}$ These procedures mandate publication in the Federal Register of proposed rules $^{\mathbf{1 5 8}}$ and allow interested parties to submit "written data, views, or arguments with or without the opportunity for oral presentation."159

This proposal also grants private citizens and environmental groups the standing to challenge alleged failures by the Secretary to perform the duties imposed by this proposal. The standing provision should be similar to that contained in the Clean Water Act, ${ }^{\mathbf{1 6 0}}$ which

151660 F.2d at 1249 n.18 (citing Camfield v. United States, 167 U.S. 518 (1897)). 1825 U.S.C. $\S \S 551-706$ (1982).

163 "Rule making" is defined as the "agency process for formulating, amending, or repealing a rule." Id. §551(5). A "rule" is defined in part as "the whole or part of an agency statement of general or particular applicability and future effect designed to implement, interpret, or prescribe law or policy or describing the organization, procedure, or practice requirements of an agency." Id. § 551(4).

154 "Adjudication" is defined as the "agency process for the formulation of an order." Id. \& 551(7). An "order" is defined as "the whole or part of a final disposition, whether affirmative, negative, injunctive, or declaratory in form, of an agency in a matter other than rule making but including licensing." Id. \& 551(6).

105 In general, agency action that involves either on-the-record rulemaking or adjudication will be enforced by a reviewing court unless the agency action is unsupported by substantial evidence. Id. $\S 706(2)(E)$. All other forms of agency action will be enforced unless the agency action is "arbitrary, capricious, an abuse of discretion or otherwise not in accordance with law." Id. § 706(2)(A). See Citizens to Preserve Overton Park, Inc. v. Volpe, 401 U.S. 402, 413-15 (1971).

${ }_{158}$ See NLRB v. Bell Aerospace Co., 416 U.S. 267 (1974).

157 See generally Administrative Procedure Act, 5 U.S.C. § 553 (1982).

${ }^{158}$ Id. \& 553(b).

${ }^{158} I d$. \& 553(c). The statute specifically exempts matters relating to "public property" from the standard notice and comment procedures. Id. § 553(a)(2). This exemption has been sharply criticized, however, and this Comment therefore suggests a statutory requirement that the Secretary's rulemaking power be exercised in accordance with the notice and comment procedures. See Bonfield, Public Participation in Federal Rulemaking Relating to Public Property, Loans, Grants, Benefits, or Contracts, 118 U. PA. L. Rev. 540 (1970).

${ }^{180}$ Federal Water Pollution Control Act, 33 U.S.C. §§ 1251-1376 (1976 \& Supp.

V 1981). 
permits private citizens to file suit when there is an alleged failure by the administrator to perform an act "which is not discretionary."161 Such a standing provision is essential to ensure that the Secretary fulfills his or her affirmative duty to confront harmful developments beyond the borders of our national parks; as noted above, one of the motivating factors behind the drafting of H.R. 2379 was a perceived failure by the Secretary to preserve and protect national park land. ${ }^{\mathbf{1 6 2}}$

Providing the Secretary with an affirmative duty and the substantive authority to issue regulations to protect our national parks from external threats vests the Secretary with far more responsibility and power than currently held. ${ }^{163}$ This newly created authority, however, is neither limitless nor free from scrutiny by the other branches of the government. For example, if the Secretary issues a regulation pursuant to this proposal that is adverse to a developer hoping to build on land adjacent to a national park, that developer can challenge the Secretary's action in court on two grounds.

First, the developer can allege that insufficient nexus exists between the proposed development and the park and that the Secretary therefore exceeded his or her powers under the statute. ${ }^{104}$ Second, in accordance with the APA, the Secretary's decisionmaking process is subject to judicial review. ${ }^{165}$ As noted by Judge Leventhal, the effect of this review is to ensure fairness in the administrative process. ${ }^{166}$ In addition to judicial review, Congress at all times remains free to supplement the Secretary's action by enacting legislation addressing the needs of a particular park, such as the BWCAWA at issue in Block. ${ }^{\mathbf{1 6 7}}$

181 Id. § 1365(a)(2).

162 See supra note 141 and accompanying text. A statutory determination, however, must be made about which of the Secretary's acts are to be deemed "not discretionary" and hence subject to the citizens' standing provision. For example, if issuing regulations to counter external threats to the national parks were deemed "not discretionary," then the potential number of private lawsuits facing the Secretary would be overwhelming. One way to limit this potential liability would be to narrow the Secretary's nondiscretionary regulation-issuing duties to dealing with the "fifty most critical" threats as determined jointly by the Secretary and Congress. See supra note 140 and accompanying text.

${ }_{163}$ Professor Sax has suggested that the National Park Service be given regulatory authority to curb only "nuisance-like" activities beyond park boundaries. Sax, Helpless Giants: The National Parks and the Regulation of Private Lands, 75 MrCH. L. REv. 239, 250-53 (1976).

184 See supra notes $90 \& 149$ and text accompanying notes 149-51.

${ }^{105}$ See supra note 155 and accompanying text.

168 "One objective is to provide supervision that emphasizes broad questions of fairness. Another objective is to combine supervision with restraint, making the courts a genuine kind of partner with the agency in the overall administrative process." Leventhal, Environmental Decisionmaking and the Role of the Courts, 122 U. PA. L. REv. 509, 554 (1974).

167 See supra notes $91-98$ and accompanying text. 
It is true, however, that this proposal may be subject to the same criticism that was raised against H.R. 2379 during the committee and House debates of that bill: regulating private activity on land adjacent to the national parks may interfere with the legitimate local interest in economic growth. ${ }^{168}$ These conflicts between national park and local economic interests are inevitable. This proposal ensures, however, that the resolution of these conflicts will occur through the observance of equitable and judicially reviewable procedures. ${ }^{169}$

\section{ConcLusion}

This Comment has examined and assessed the viability of several alternatives for protecting the national parks from developments outside their borders that adversely affect the parks themselves. Nuisance law and the doctrine of public trust are two sources for such protection that have been used with some success recently. Although the nuisance and public trust doctrines have potential for involving courts in the process of protecting parks from threats beyond their borders, truly effective protection is likely to come only via congressional legislation. The Comment has asserted that existing and proposed legislation is inadequate for coping with these threats. Congress, however, might provide adequate protection for the parks by carefully delineating the duties and authority of the Secretary of the Interior to deal with such developments. Court interpretations of the United States Constitution have indicated that Congress is vested with the power to provide for the protection of the public lands. It remains with Congress effectively to implement that power to protect the nation's culturally significant and unique natural lands from deterioration.

${ }^{168}$ See supra note 126 and text accompanying notes 125-29.

168 In addition to the methods of review described in this proposal, an aggrieved state is free to claim that the Secretary's action interferes with powers reserved to the states by the tenth amendment. Such a claim was raised unsuccessfully by the state of Minnesota in the Block case. See supra notes $97-98$ and accompanying text. 